\title{
Edge effect on post-dispersal artificial seed predation in the southeastern Amazonia, Brazil
}

\author{
Penido, G. ${ }^{a *}$, Ribeiro, $V^{a}$ and Fortunato, DS. ${ }^{a}$ \\ aPrograma de Pós-Graduação em Ecologia, Departamento de Zoologia, Universidade de Brasília - UnB, \\ Campus Universitário Darcy Ribeiro, Brasília, CEP 70910-900, Brasília, DF, Brazil \\ *e-mail: g.penido@yahoo.com.br
}

Received: July 16, 2013 - Accepted: December 17, 2013 - Distributed: May 31, 2015

(With 3 Figures)

\begin{abstract}
This paper evaluates the post-dispersal artificial seed predation rates in two areas of the southeastern Amazon forest-savanna boundary, central Brazil. We conducted the survey in a disturbance regime controlled research site to verify if exists an edge effect in these rates and if the disturbance (in this case annual fire and no fire) affects seed predation. We placed 800 peanuts seeds in each area at regular distance intervals from the fragment's edge. Data were analyzed by a likelihood ratio model selection in generalized linear models (GLM). The complete model (with effects from edge distance and site and its interaction) was significative $\left(\mathrm{F}_{3}=4.43 ; \mathrm{p}=0.005\right)$. Seeds had a larger predation rates in fragment's interior in both areas, but in the controlled area (no disturbance) this effect was less linear. This suggests an edge effect for post-dispersal seed predation, and that disturbances might alter these effects. Even if we exclude the site effect (grouping both areas together) there is still a strong edge effect on seed predation rates $\left(\mathrm{F}_{3}=32.679 ; \mathrm{p}>0.001\right)$. We did not verify predator's species in this study; however, the presence of several species of ants was extremely common in the seeds. The detection of an edge effect in only a short survey time suggests that there is heterogeneity in predation rates and that this variation might affect plant recruitment in fragmented areas of the Amazon forest. Henceforth, this seed predation should be taken in consideration in reforestation projects, where the main source of plants species is from seed distribution.
\end{abstract}

Keywords: Amazon Forest, edge effect, seed predation.

\section{Efeito de borda na predação de sementes artificiais pós-dispersão no sudeste da Amazônia, Brasil}

\section{Resumo}

Este artigo avaliou a predação de sementes pós-dispersão em duas áreas da borda entre a Amazônia e o Cerrado, no Brasil central. O experimento foi realizado em uma área de estudos controlados, no qual foi verificada a existência de um efeito de borda na predação de sementes e se a existência de distúrbio (área sujeita a fogo anual e área controle) afeta estes valores. Foram colocadas 800 sementes de amendoim em cada uma das duas áreas em distância regulares da borda do fragmento. Os dados obtidos foram analisados através de seleção de modelos por verossimilhança em modelos lineares generalizados (GLM). O modelo completo (com efeitos da distância da borda e da área amostrada com suas interações) foi significativo $\left(\mathrm{F}_{3}=4,43 ; \mathrm{p}=0,005\right)$. As sementes apresentaram uma maior taxa de predação no interior do fragmento em relação a sua borda em ambas as áreas, mas na área controle (sem distúrbio), o efeito foi menos linear. Isto sugere que existe um efeito de borda para a predação de sementes, e que distúrbios podem alterar estes efeitos. Mesmo se o efeito das áreas for removido (considerando ambas as áreas em conjunto), o efeito de borda sobre a predação de sementes persiste $\left(\mathrm{F}_{3}=32,679 ; \mathrm{p}>0,001\right)$. Não foram verificadas diretamente as espécies de predadores neste estudo, no entanto a presença de algumas espécies de formigas nas sementes foi extremamente comum. A deteç̧ão deste efeito de borda em um espaço de tempo curto sugere que existe uma heterogeneidade nas taxas de predação e que esta variação pode afetar o recrutamento vegetal em áreas fragmentadas da floresta amazônica. Portanto, este efeito sobre a predação de sementes deve ser levado em consideração em projetos de reflorestamento, nos quais a principal fonte de espécies vegetais seja através da distribuição de sementes.

Palavras-chave: Floresta Amazônica, efeito de borda, predação de sementes. 


\section{Introduction}

Post-dispersal seed predation is an important factor regulating plant community composition and structure (Diaz et al., 1999; Nathan and Muller-Landau, 2000; Baldissera and Ganade, 2005). Seed mortality due predation may affect fitness, population structure and species composition in a forest community (Schupp, 1990; Willson and Whelan, 1990; Wong et al., 1998; Diaz et al., 1999). In tropical environments, a high proportion of seeds are consumed by predators (Holl and Lulow,1997), however, predators activity are affected by local physical (e.g. temperature) and biological (e.g. prey density) characteristics (Diaz et al., 1999), which in turn, changes the nature and proportion of seed predation accordingly to the local habitat in which the seed is located (Willson and Whelan, 1990; Whelan et al., 1991; Vasquez et al., 1995; Sánchez-Cordero and Martinez-Gallardo, 1998). Different factors, like plant species composition and community structure might affect seed predation (Holl and Lulow, 1997). Previous works also demonstrated that the predation rate might differ between preserved and disturbed areas (Aide and Cavelier, 1994; Stevens and Husband, 1998; Baldissera and Ganade, 2005).

Habitat fragmentation is one of the main negative effects of human activity on biodiversity (Vitousek et al., 1997; Laurance et al., 2007). This fragmentation can have deleterious effects on the present biota (Murcia, 1995; Wong et al., 1998) for a number of reasons, for example through the edge effect - physical and biological alteration in several characteristics associated with fragments borders (Laurance et al., 2007). Alterations in environmental quality are stronger in fragments since there is a larger proportion of an edge habitat in small fragments in relation to large continuous areas (Hoover et al., 1995). These alterations can have a direct effect on local plant recruitment, through microclimatic alterations - humidity, light, and temperature - or an indirect effect, by changing activity and behavior of predator's species (Diaz et al., 1999).

In this last case, seed predation rates may increase as the activity of generalist predator species, adapted to edge environments, may extend further into the fragment (Wilcove, 1985), or decrease, due to edge aversion of some predator species (Burkey, 1993). Several studies investigated the existence of a relation between seed predation rates and edge distance (Whelan et al., 1991; Burkey, 1993; Wong et al., 1998; Sodhi et al., 2003; Holl and Lulow, 1997; Guzmán-Guzmán and Williams-Linera, 2006). Most studies found a higher seed predation rate deep into the fragment than near the edges (Burkey, 1993; Restrepo and Vargas, 1999). Burkey (1993) suggests that this pattern is caused by seed predators' avoidance of edge habitats given that these species would be more easily preyed in this area. However, this and others authors considers small rodents to be the main seed predators, excluding from their analysis seed predation by ants species (Whelan et al., 1991; Diaz, 1992; Diaz et al., 1999; Holl and Lulow, 1997), a predators species that may limit plant recruitment (Weeny,
2000). A study in Brazil found that the predation of seeds by ants is higher in edge areas than fragment interior (Guimarães-Junior and Cogni, 2002). Therefore, factors associated with different predators may affect the edge effect on seed predation rates.

Other factor, fragment structure, may relate to seed predation rates indirectly, by altering predator's behavior (Diaz et al., 1999) which could have different activity patterns in areas with different vegetal structure (Myster and Pickett, 1993) with the more complex is the vegetation structure, bigger are the predation rates (Myster and Pickett, 1993) reflecting, maybe, a preference of predators to dense forest cover. Even in the same region and vegetation type, fragment age and disturbance nature may alter structure of an edge habitat (Restrepo et al., 1999; Ferreira et al., 2011) changing seed predation rates.

One type of disturbance that might affect seed predation rates and forest structure is fire, (Cochrane and Schulze, 1999; Balch et al, 2008). This might happen through several factors, for example: the number of leaf-cutting ants' (Atta spp.) nests increases in disturbed areas (Wirth et al., 2007; Meyer et al., 2009) including fire disturbance (Carvalho et al., 2012). These ants species affects plant recruitment increasing (by seed dispersion) or decreasing (by seed predation and herbivory) altering the forest structure. Consequently, burned areas might alter seed predation rates.

The objective of this study was to assess if there is an edge effect on post-dispersal seed predation rates in a fragment in the southeastern Amazon forest-savanna boundary, and if different regimes of controlled fire alter this effect. This raises two questions: First, do seed predators avoid of prefer edge habitats? Secondly, do sites with a history of different fire pressures alter the behavior of these predators? The answer to these questions might help explain how plant species communities respond to disturbance and edge creation in the Amazon forest.

\section{Material and Methods}

Study area: The study was conducted in a private farm (Fazenda Tanguro), located in Mato Grosso State at the southern Amazon border (13 ${ }^{\circ} 04$ ' 35' S, 52 23 ' 08' W) (Figure 1). For the analysis, we selected an area of 150 ha, divided in three separated blocks of 50 ha each, under a special fire regime (control, annual fire and triennial fire).

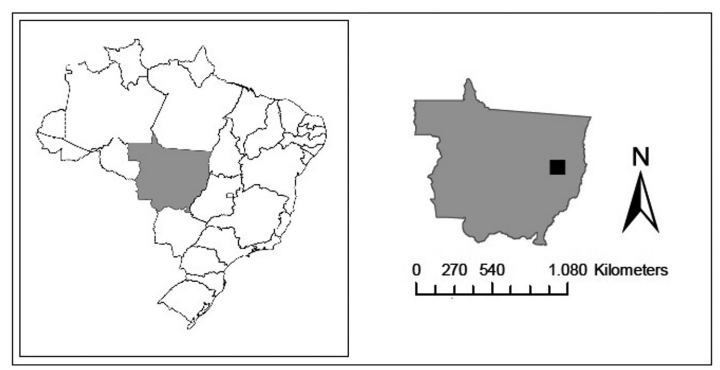

Figure 1. Map showing the location of the Tanguro farm in the Mato Grosso State, Brazil. 
We surveyed two blocks (F0 and F1, control and annual fire, respectively). The fragments share the edge with a large-scale soybean plantation.

Survey Design: For each block (F0 and F1) we made four transects at different distances to the edge $(0,50$, 150 and 250 meters). Edge limit was considered to be the first tree or shrub nearer to the soybean plantation. In each transect we placed, 20 samples points along the borders' limit, spaced by $15 \mathrm{~m}$ from each other. Each sample point consisted of 10 peanuts seeds (Arachis hypogaea L.) randomly placed at 2 to 3 meters of the transaction line, always near however, to a tree or a distinctive mark in order to facilitate seeds future inspections. The utilization of peanuts, an exotic species - was made with the intent to verify the seed predation rates excluding the possibility of conduct the survey with a local seed species that might be associated with a specific predator, which might have created a bias in the results (Burkey, 1993; Wong et al., 1998). We checked each sample point 4 days after seed placement.

Statistical analysis: Each sample point (i.e. group of ten seeds) we considered the detection (success) probability for each individual seed. In other words: if in a sample point, three seeds were preyed we considered a predation probability of 0.3 for this point. This success rate were, then, used for comparisons between the areas and distances to the edge in order to verify if there is any pattern on seed predation.

These data were analyzed by a likelihood ratio model selection in generalized linear models (GLM). We begun with the complete model (i.e. distance and site effects and its interactions), removing, sequentially, the lowest effect variable from the model until all not significant variables are removed leaving only the most significant and parsimonious model. Model significance is considered the actual significance of variable removal, i.e., the loss of explication power by that variable removal. At the end the selected model, if significant, is compared with the null model after all assumptions are validated.

All analysis was made in Software R.3.0.0 (R Core Team, 2013). As the data qualifies as a count data, we used the Poisson family dispersion parameters for the analysis.

\section{Results}

The results of the GLM presented an over dispersion (3.33, when it should be 1.0 for this family), so we choose to apply a quasi-likelihood (Quasi-Poisson) method that allows over dispersion, adjusting the dispersion to approximate the estimated parameters.

The complete model (M1), was considered to be significative $\left(\mathrm{F}_{3}=4.43 ; \mathrm{p}=0.005\right)$. In this model, both distance to the edge and sites differed in seed predation with an interaction between these two variables. Seeds had a tendency of larger predation in the fragment interior (Figure 2), however there is an abruptly fall in predation at $50 \mathrm{~m}$ in the control site, F0, increasing afterwards. This fall is likely to be responsible for the site effect on the analysis, differentiating between F0 and F1.
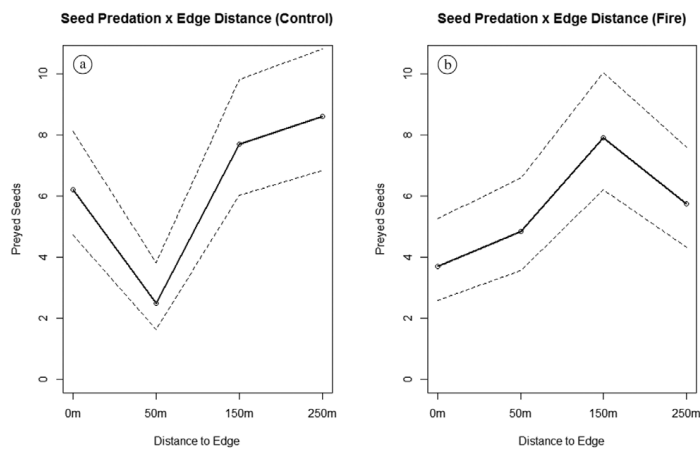

Figure 2. Mean preyed seeds for each distance for both areas independently: (a) control site F0, and (b) annual fire F1. Dashed line indicates 95\% Confidence Interval.

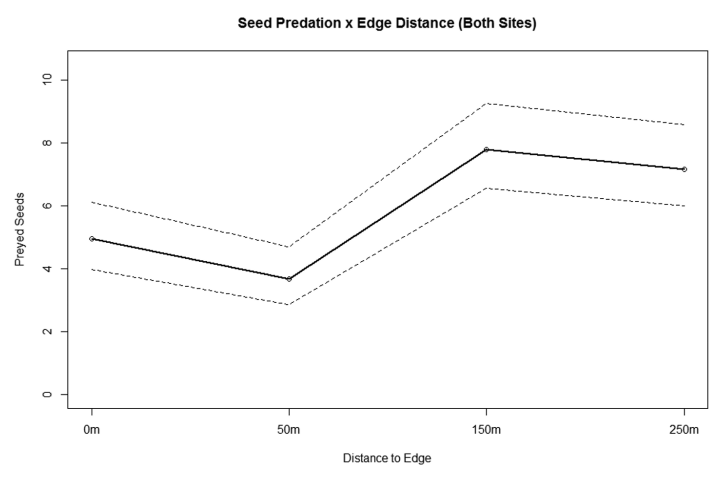

Figure 3. Mean preyed seeds for each distance for both areas jointly. Dashed line indicates 95\% Confidence Interval.

If we consider this to be true and perform the analysis excluding the site effect (placing together both sites) there still a strong distance effect on seed predation $\left(\mathrm{F}_{3}=32.679\right.$; $\mathrm{p}>0.001)$ with more seeds being preyed in fragment interior (Figure 3).

\section{Discussion}

The results suggest a possible edge effect for seed predation in this area. In accordance with previous studies (Burkey, 1993; Diaz et al., 1999; Guzmán-Guzmán and Williams-Linera, 2006), post-dispersal seed predation rates were lesser in the edge than in the fragment interior. However, the increasing in predation rates were only for distances larger than $50 \mathrm{~m}$, and differing from those previous studies, predation rates were higher in the edge than $50 \mathrm{~m}$ distance. The differing matrix surrounding the fragment between these studies might be the reason for this variation near the edge, since in our study, the soybean matrix could attract seed predators.

As previously discussed, the majority of studies on seed predation does not take in consideration ant species. Despite that predators' species identification were not an objective of this current study, the occurrence ants predating the peanut seeds at samples points was very common, predominantly at the edge. A previous study 
described a larger post-dispersal seed predation in edge habitats by ant species (Guimarães-Junior and Cogni, 2002). Some ant species have a larger density in forest edges - up to $50 \mathrm{~m}$ - (Wirth et al., 2007), which may be one factor on why we had a larger predation rate near the edge than $50 \mathrm{~m}$ from it.

The difference between predation in the two blocks (F0 and F1), was probably due to the larger predation rate at $50 \mathrm{~m}$ in the control site than in the fire site. The vegetation structure of the sites differed at this distance from the edge, with the control site having a denser and more complete cover than the relatively open environment of the fire site. Some seed predators might avoid open areas due to fear of predation. Even if this difference between sites is a real effect for the area, the edge effect remains, with more seeds preyed in the interior than in the edges in both areas suggesting that, even with the fire disturbance and different vegetation structures, the edge effect is a factor affecting seed predation rates at this site.

It should be noted that natural and artificial predation rates might differ (Wong et al., 1998). The utilization of exotic seed species in this artificial experiment does not allow a precise estimate of the natural predation rates in this site (Wong et al., 1998). It is possible, however, to deduce the seed predation pressure by predators, which in turn, may be used to estimate seeds vulnerability at community level (Sieving, 1992) creating a estimative of relative predation rates for the community (Loiselle and Hoppes, 1983; Wilcove, 1985).

The detection of an edge effect in only a short survey time suggests that there is heterogeneity in predation rates and that this variation might affect plant recruitment in fragmented areas of the Amazon forest. Henceforth, this seed predation should be taken in consideration in reforestation projects, where the main source of plants species is from seed distribution (Diaz et al., 1999). Generalist predators might highly reduce plant recruitment in fragment interior, and in edge habitats, the effect of ant's predation should not be relegated.

\section{Acknowledgements}

We would like to thank the University of Brasilia Graduate Program in Ecology for the financial support and to Drs. Ricardo Machado, Guarino Colli and Ludmilla Aguiar from University of Brasilia (UnB) and to Dr. Eddie Lenza from Mato Grosso State University (UNEMAT) - for all support on the study design. We would also like to thank the Instituto de Pequisa Ambiental da Amazônia (IPAM) for all the logistical support during the surveys. The authors received scholarship grants from Coordenação de Aperfeiçoamento de Pesssoal de Nível Superior (CAPES).

\section{References}

AIDE, TM. and CAVELIER, J., 1994. Barriers to lowland Tropical Forest restoration in the Sierra Nevada de Santa Marta, Colombia. Restoration Ecology, vol. 2, no. 4, p. 219-229. http:// dx.doi.org/10.1111/j.1526-100X.1994.tb00054.x.
BALCH, JK., NEPSTAD, DC., BRANDO, PM., CURRAN, LM., PORTELA, O., CARVALHO JUNIOR, O. and LEFEBVRE, P., 2008. Negative fire feedback in a trasitional forest of southeastern Amazonia. Global Change Biology, vol. 14, no. 10, p. 2276-2287. http://dx.doi.org/10.1111/j.1365-2486.2008.01655.x.

BALDISSERA, R. and GANADE, G., 2005. Predação de sementes ao longo de uma borda de Floresta Ombrófila Mista e pastagem. Acta Botanica Brasilica, vol. 19, no. 1, p. 161-165. http://dx.doi. org/10.1590/S0102-33062005000100016.

BURKEY, TV., 1993. Edge effects in seed and egg predation at two neotropical rainforest sites. Biological Conservation, vol. 66, no. 2, p. 139-143. http://dx.doi.org/10.1016/0006-3207(93)90145-Q.

CARVALHO, KS., BALCH, J. and MOUTINHO, P., 2012. Influências de Atta spp. (Hymenoptera: Formicidae) na recuperação da vegetação pós-fogo em floresta de transição amazônica. Acta Amazonica, vol. 42, no. 1, p. 81-88. http://dx.doi.org/10.1590/ S0044-59672012000100010.

COCHRANE, MA. and SCHULZE, MD., 1999. Fire as a recurrent event in Tropical Forests of the Eastern Amazon: effects on forest structure, Biomass, and Species Composition. Biotropica, vol. 31 , p. 2-16.

DIAZ, I., PAPIC, C. and ARMESTO, J., 1999. An assessment of post-dispersal seed predation in temperate rain forest fragments in Chiloe Island, Chile. Oikos, vol. 87, no. 2, p. 228-238. http:// dx.doi.org/10.2307/3546738.

DIAZ, M., 1992. Rodent seed predation in cereal crop areas of central Spain: effects of physiognomy, food availability, and predation risk. Ecography, vol. 15, no. 1, p. 77-85. http://dx.doi. $\operatorname{org} / 10.1111 / \mathrm{j} .1600-0587.1992 . t b 00011 . x$.

FERREIRA, AV., BRUNA, EM. and VASCONCELOS, HL., 2011. Seed predators limit plant recruitment in Neotropical savannas. Oikos, vol. 120, no. 7, p. 1013-1022. http://dx.doi. org/10.1111/j.1600-0706.2010.19052.x.

GUIMARÃES-JUNIOR., P. and COGNI, R., 2002. Seed cleaning of Cupania vernalis (Sapindaceae) by ants: edge effect in a highland forest in south-east Brazil. Journal of Tropical Ecology, vol. 18, p. 303-307.

GUZMÁN-GUZMÁN, J. and WILLIAMS-LINERA, G., 2006. Edge effect on acorn removal and oak seedling survival in Mexican lower montane forest fragments. New Forests, vol. 31, no. 3, p. 487-495. http://dx.doi.org/10.1007/s11056-005-2015-0.

HOLL, K. and LULOW, M., 1997. Effects of species, habitat, and distance from edge on post-dispersal seed predation in a Tropical Rainforest. Biotropica, vol. 29, no. 4, p. 459-468. http://dx.doi. org/10.1111/j.1744-7429.1997.tb00040.x.

HOOVER, JP., BRITTINGHAM, MC. and GOODRICH, LJ., 1995. Effects of forest patch size on nesting success of wood thrushes. The Auk, vol. 112, no. 1, p. 146-155. http://dx.doi. org/10.2307/4088774

LAURANCE, WF., NASCIMENTO, HEM., LAURANCE, SG., ANDRADE, A., EWERS, RM., HARMS, KE., LUIZÃO, RCC. and RIBEIRO, JE., 2007. Habitat fragmentation, variable edge effects, and the landscape-divergence hypothesis. PLoS $O N E$, vol. 2, no. 10, p. e1017. http://dx.doi.org/10.1371/journal. pone.0001017. PMid: 17925865

LOISELLE, B. and HOPPES, W., 1983. Nest predation in insular and Mainland Lowland Rainforest in Panama. The Condor, vol. 85, no. 1, p. 93-95. http://dx.doi.org/10.2307/1367897. 
MEYER, ST., LEAL, IR. and WIRTH, R., 2009. Persisting hyperabundance of leaf-cutting ants (Atta spp.) at the edge of an old Atlantic forest fragment. Biotropica, vol. 41, no. 6, p. 711-716. http://dx.doi.org/10.1111/j.1744-7429.2009.00531.x.

MURCIA, C., 1995. Edge effects in fragmented forests: implications for conservation. Trends in Ecology \& Evolution, vol. 10, no. 2, p. 58-62. http://dx.doi.org/10.1016/S0169-5347(00)88977-6. PMid:21236953

MYSTER, RW. and PICKETT, STA., 1993. Effects of litter, distance, density and vegetation patch type on postdispersal tree seed predation in old fields. Oikos, vol. 66, no. 3, p. 381-388. http://dx.doi.org/10.2307/3544932.

NATHAN, R. and MULLER-LANDAU, HC., 2000. Spatial patterns of seed dispersal, their determinants and consequences for recruitment. Trends in Ecology \& Evolution, vol. 15, no. 7, p. 278-285. http://dx.doi.org/10.1016/S0169-5347(00)01874-7. PMid:10856948

R CORE TEAM., 2013. R: A Language and Environment for Statistical Computing. Vienna: R Foundation for Statistical Computing. Version 3.0.1.

RESTREPO, C., GOMEZ, N. and HEREDIA, S., 1999. Anthropogenic edges, treefall gaps, and fruit-frugivore interactions in a Neotropical Montane Forest. Ecology, vol. 80, p. 668-685.

RESTREPO, C. and VARGAS, A., 1999. Seeds and seedlings of two neotropical montane understory shrubs respond differently to anthropogenic edges and treefall gaps. Oecologia, vol. 119, no. 3, p. 419-426. http://dx.doi.org/10.1007/s004420050803.

SÁNCHEZ-CORDERO, V. and MARTINEZ-GALLARDO, R., 1998. Postdispersal fruit and seed removal by forest-dwelling rodents in a lowland rainforest in Mexico. Journal of Tropical Ecology, vol. 14, no. 2, p. 139-151. http://dx.doi.org/10.1017/ S0266467498000121.

SCHUPP, E., 1990. Annual variation in seedfall, postdispersal predation, and recruitment of a neotropical tree. Ecology, vol. 71, no. 2, p. 504-515. http://dx.doi.org/10.2307/1940304.

SIEVING, K., 1992. Nest predation and differential insular extinction among selected forest birds of Central Panama. Ecology, vol. 73, no. 6, p. 2310-2328. http://dx.doi.org/10.2307/1941477.

SODHI, NS., PEH, KSH., LEE, TM., TURNER, IM., TAN, HTW., PRAWIRADILAGA, DM. and DARJONO., 2003. Artificial nest and seed predation experiments on tropical southeast Asian islands. Biodiversity and Conservation, vol. 12, p. 2415-2433. http://dx.doi.org/10.1023/A:1025852214528.

STEVENS, SM. and HUSBAND, TP., 1998. The influence of edge on small mammals : evidence from Brazilian Atlantic forest fragments. Biological Conservation, vol. 85, no. 1-2, p. 1-8. http:// dx.doi.org/10.1016/S0006-3207(98)00003-2.

VASQUEZ, RA., BUSTAMANTE, RO. and SIMONETTI, JA., 1995. Granivory in the Chilean matorral: extending the information on arid zones of South America. Ecography, vol. 18, no. 4, p. 403-409. http://dx.doi.org/10.1111/j.1600-0587.1995.tb00143.x.

VITOUSEK, PM., MOONEY, HA., LUBCHENCO, J. and MELILLO, JM., 1997. Human domination of Earth's ecosystems. Science, vol. 277, no. 5325, p. 494-499. http://dx.doi.org/10.1126/ science. 277.5325 .494

WEENY, DG., 2000. Seed dispersal, ssed predation and seedling recruitment of a neotropical montane tree. Ecological Monographs, vol. 70, no. 2, p. 331-351. http://dx.doi.org/10.1890/00129615(2000)070[0331:SDSPAS]2.0.CO;2.

WHELAN, CJ., WILLSON, MF., TUMA, CA. and SOUZAPINTO, I., 1991. Spatial and temporal patterns of postdispersal seed predation. Canadian Journal of Botany, vol. 69, no. 2, p. 428-436. http://dx.doi.org/10.1139/b91-059.

WILCOVE, D., 1985. Nest predation in forest tracts and the decline of migratory songbirds. Ecology, vol. 66, no. 4, p. 12111214. http://dx.doi.org/10.2307/1939174.

WILLSON, M. and WHELAN, C., 1990. Variation in postdispersal survival of vertebrate-dispersed seeds: effects of density, habitat, location, season, and species. Oikos, vol. 57, no. 2, p. 191-198. http://dx.doi.org/10.2307/3565939.

WIRTH, R., MEYER, ST., ALMEIDA, WR., ARAÚJO, MV., BARBOSA, VS. and LEAL, IR., 2007. Increasing densities of leaf-cutting ants (Atta spp.) with proximity to the edge in a Brazilian Atlantic forest. Journal of Tropical Ecology, vol. 23, no. 04, p. 501-505. http://dx.doi.org/10.1017/S0266467407004221.

WONG, T., SODHI, N. and TURNER, I., 1998. Artificial nest and seed predation experiments in tropical lowland rainforest remnants of Singapore. Biological Conservation, vol. 85, no. 1-2, p. 97-104. http://dx.doi.org/10.1016/S0006-3207(97)00145-6. 